\title{
Elmi-texnoloji innovasiya parklarının informasiya təhlükəsizliyi problemləri
}

\author{
Roza Şahverdiyeva \\ AMEA İnformasiya Texnologiyaları İnstitutu, Bakı, Azərbaycan \\ shahverdiyevar@gmail.com
}

\begin{abstract}
Xülasə -Məqalə elmi-texnoloji innovasiya texnoparklarının informasiya sistemləri və texnologiyalarının təhlükəsizliyi problemlərinə həsr olunmuşdur. İnnovasiya texnoparklarının informasiya və biliklər iqtisadiyyatında rolu, vəzifələri, əhəmiyyəti izah olunmuşdur. Onların idarə olunmasında müasir informasiya təminatı sisteminin əsas struktur elemenləri vo informasiya təminatının yaxşılaşmasına təsir edən amillər şərh olunmuşdur. Texnoparkların informasiya sistemləri, resursları və texnologiyalarının təhlükəsizliyinin formalaşma mərhələləri verilmişdir. İnformasiya təhlükəsizliyi sisteminin arxitekturtexnoloji strukturu iş̧ənilmiş və onun təkmilləşdirilməsi üzrə bəzi tövsiyyələr verilmişdir.

Açar sözlor - informasiya vo biliklor iqtisadiyyatı; elmi-texnoloji innovasiya texnoparki; informasiya sistemlorinin tohlükosizliyi; informasiya tominatt vo vo tohlükəsizliyi; tohlükəsizlik metodları.
\end{abstract}

\section{GİRIŞ}

Beynəlxalq səviyyədə iqtisadi inkişaf daha çox innovasiyalara, yeni texnologiyalara, biliklərə əsasalanır. $\mathrm{Bu}$ istiqamətdə elm-təhsil-istehsalat sahələri arasında qarşılıqlı əlaqələrin gücləndirilməsi məqsədilə yeni idarəetmə mexanizmlərinin işlənilməsi, innovasiya mərkəzlərinin, texnoloji komplekslərin, texnoparkların, biznes-inkubatorların yaradılması və fəaliyyətinin təşkili məsələləri nəzərdə tutulmuşdur [1, 2].

Hal-hazırda ölkədə informasiya resursları və proseslərinin mühafizəsi, onların sabitliyi və fasiləsizliyi həyata keçirilir. İnformasiya ehtiyatlarının qorunması sahəsində təhdidlərin qarşısı alınır. Təhlükələrin təhlili və onların aradan qaldırılması üçün informasiya infrastrukturu subyektlərinin, onların istifadəçilərinin fəaliyyətinin əlaqələndirilməsi sahəsində tədbirlər görülür. Eyni zamanda kibertəhlükəsizlik sahəsində risklərin qiymətləndirilməsi və idarə olunması məqsədi ilə informasiya təhlükəsizliyi üzrə fəaliyyətin təkmilləşdirilməsi istiqamətində tədbirlər həyata keçirilir.

İnnovativ iqtisadiyyatın davamlı inkişafina və rəqabət qabiliyyətinin artırılmasına yeni texnologiyaların işlənilməsi üzrə müasir komplekslərin yaradılmasına nail olmaq üçün Sumqayıt sənaye və kimya texnologiyası parkı, NRYTN-də "Yüksək texnologiyalar parkı", Balaxanıda eko-sənaye parkı, AMEA-da Yüksək Texnologiyalar Parkı, regionlarda aqro və digər yüksək texnologiyalar parkı yaradılmışdır. Onların və onlar kimi digər innovasiya strukturlarının əsas idarə etmə problemlərindən biri də informasiya resurslarının, sistemlərinin, texnologiyalarının təhlükəsizliyinin təmin edilməsi məsələsidir.

Texnoparklar mahiyyət və məzmun etibarı ilə digər iqtisadi strukturlardan daha çox yeniliyi, elmi və texnoloji tutumu, "Nou-hau”ların çoxluğu, elmi-tədqiqatların innovativliyi, elmi-texniki kommersiya sirləri, müəllif hüquqlarının daha ciddi qorunması zərurəti, intellektual mülkiyyət məsələlərinə daha çox diqqət yetirilməsi və s. ilə fərqlənir. Bütün bunlar elmi-texnoloji innovasiya texnoparklarının informasiya sistemləri və texnologiyalarının təhlükəsizliyi problemlərinin, informasiya təminatının və onun təhlükəsizliyinin spesifikliyinin nəzərə alınmasını və həmin sahədə müvafiq metod və mexanizmlərin işlənilməsini zəruri edir.

\section{ELMI-TEXNOLOJI INNOVASIYA PARKLARININ IQTISADIYYATDA ROLU VӘ VӘZIFӘLӘRI}

Hər bir ölkənin iqtisadi inkişafinda elmi-texnoloji innovasiya texnoparkları əhəmiyyətli rola malikdir. Çünki Informasiya və biliklər iqtisadiyyatının infrastrukturunun əsasını elmi-texnoloji innovasiya texnoparkları təşkil edir. İnnovasiya yönümlü, informasiya və biliyə əsaslanan iqtisadiyyatın qurulmasında yüksək texnologiyalar, innovativ parklarının yaradılması əsas məqsədlərdəndir. Rəqəmsal və ya innovativ iqtisadiyyata keçid üçün yüksək texnologiyalar park1, elm-texnoloji innovasiya texnoparkları əsas hərəkətverici qüvvədir.

Texnoparkların yaradılmasının əsas xüsusiyyətlərinə: 1) innovativ xarakterli müəssisə olması, 2) elmin, təhsilin, istehsalın və kommersiyanın maksimal olaraq bir-birinə yaxınlaşdırılması, 3) müxtəlif stimullaşdırma mexanizmlərinin və rejimlərinin tətbiq edilməsi, 4) yüksək texnologiyalar, o cümlədən İKT əsasında məhsul və xidmətlərin artırılması, 5) elm və texnologiya tutumlu firmaların inkişaf etdirilməsi, 6) intellektual beyin məhsulunun işlənilməsi, 7) yüksək texnologiyalar sektorunun inkişaf etdirilməsi, 8) elmi-tədqiqat işlərinin nəticələrinin sürətlə reallaşması, 9) regional büdcənin gəlirlərinin artırılması, 10) innovativ texnologiyaların transferi, 11) intellektual mülkiyyətin qorunması, 12) kollektiv istifadə mərkəzlərinin formalaşdırılması və s. daxildir [3, 4, 5].

İnformasiya təminatı və təhlükəsizlik məsələləri ümumi halda texnoparkların idarə edilməsi sisteminin funksiyalarından da asılıdır. Həmin funksiyalara aşağıdakılar 


\section{“Informasiya tohlükosizliyinin aktual multidissiplinar elmi-praktiki problemlori” IV respublika konfransı, 14 dekabr 2018-ci il}

daxildir: 1)texnoparkların fəaliyyətində güzəştli şərtlər, elmitədqiqat və təcrübə-konstruktor işlərinin yerinə yetirilməsi üçün əlverişli şəraitin yaradılması, 2)rezident-şirkətlərin fəaliyyəti üçün əlverişli şəraitin olması, 2)innovasiya müəssisələrinin dəstəklənməsi sisteminin formalaşdırılması, 3)kiçik innovasiya müəssisələrinə konsaltinq, mühəndis, texniki, texnoloji, informasiya və digər xidmətlərin göstərilməsində yardım etmək, 4)innovasiyalı məhsulun üzə çıxarılması, seçim və istehsalda tətbiqinə qədər onların müşayiət olunmas1, 5)qərar qəbuletməyə dəstək məqsədilə intellektual informasiya sisteminin işlənilməsi və $\mathrm{s}$. Texnoparklarda məhsulun istehsalı, müəyyən bir innovativ proseslə xarakterizə olunur. Ümumi halda innovasiya prosesinə yeni kəşfin, texnologiyanın, məhsul və xidmətin, intellektual fəaliyyətin kommersiyalaşdırılması kimi baxıla bilər. Bu prosesin strukturuna bir çox mərhələləri daxil etmək olar [6].

Yeni texnologiyaların texnopark və digər innovativ müəssisələrin idarə etmə sahələrinə tətbiq olunması innovasiya fəaliyyəti ilə xarakterizə olunur. Texnoparklarda innovasiya fəaliyyəti əhatəli və çox istiqamətlidir. Ona görə də belə fəaliyyəti həm ayrı-ayrılıqda olan göstəricilərlə, həm də qrup və istiqamətlərdə birləşən göstəricilərlə xarakterizə edirlər [7]. Texnoparklarda innovasiya fəaliyyəti üzrə 1) müəssisənin innovativ aktivliyi, 2)müəssisələrdə elmi-tədqiqat bölməsinin mövcudluğu, 3)daxili və xarici bazarlardakı satışın həcmində innovasiya məhsul və xidmətlərinin strukturu, xüsusi çəkisi, 4)innovasiya fəaliyyəti nəticələrinin reytinq göstəriciləri, 5)ölkə və regionlar üzrə innovasiya fəaliyyəti ilə məşğul olan innovativ müəssisələrin strukturu, 6)maliyyə mənbələri üzrə innovasiya xərclərinin strukturu, 7)innovasiya fəaliyyəti növləri üzrə xərclərin strukturu və xüsusi çəkisi, 8)innovasiya üzrə məlumat mənbələrinin reytinqi, 9)texnoloji innovasiyalara mane olan faktorların reytinqi və s. kimi əsas göstəriciləri təhlil etmək lazımdır $[8,5,9]$.

Göstərilən xüsusiyyətlər, mərhələlər və göstəricilər innovasiyanın formalaşmasına birbaşa təsir etdiyi kimi, onlarla əlaqədə olan informasiya təminatı və təhlükəsizliyi məsələlərinin müəyyənləşdirilməsi və həlli istiqamətlərinin işlənilməsinə də bilavasitə təsir edir.

\section{ELMI-TEXNOLOJI INNOVASIYA PARKLARININ INFORMASIYA SISTEMLORININ TӘHLÜKӘSIZLIYI}

Elmi-texnoloji innovasiya texnoparklarının informasiya sistemlərinin təhlükəsizliyi məsələləri kompleks xarakter daşıyir. Həmin məsələlər istənilən innovativ müəssisənin, texnoparkların yerinə yetirdiyi funksiyalardan asılıdır. $\mathrm{Bu}$ səbəbdən də innovativ elmi texnoparklarda informasiya təhlükəsizliyinin idarə olunmasının bəzi aspektləri tədqiqat işlərində əks olunmuşdur. [10]-də innovasiya müəssisələrində informasiya təhlükəsizliyinin idarəedilməsinə təsir edən faktorlar araşdırılmışdır. Göstərilmişdir ki, hazırda informasiya müəssisənin ən əhəmiyyətli kapitalı hesab edilir və o aparıcı rola malikdir. Müxtəlif müəssisələrdə informasiya təhlükəsizliyinə qoyulan tələblər müxtəlif təhlükəsizlik tədbirlərinin tətbiqini tələb edir. İnformasiyanın təhlükəsizlik nöqteyi-nəzərindən hərtərəfli qorunması və saxlanılması üçün böyük səylər göstərilməlidir. Məqalədə İran və Türkiyə nümunəsində olan innovasiya müəssisələrində informasiyanın idarə edilməsi məsələsi tədqiq edilmişdir. Türkiyə təcrübəsi əsasında toplanılmış analoji məlumatlarla alınmış nəticələr müqayisə edilmişdir. Aparılan tədqiqat bir çox müəssisələrin təcrübəsi əsasında həyata keçirilmişdir.

[11]-də isə Türkiyə nümunəsində innovasiya müəssisələrində informasiya təhlükəsizliyinin idarə olunmasına təsir edən amillər araşdırılmışdır. İnnovasiya müəssisələrində korporativ informasiya təhlükəsizliyi araşdırılmış və nəticələr müxtəlif ölkələrdən toplanan oxşar informasiyalarla müqayisə edilmişdir. $\mathrm{Bu}$ araşdırmanın nəticələrinə görə şirkətlərdə digər təhlükəsizlik tədbirləri kommunikasiya, əməliyyatlar və təhlükəsizlik siyasətinin yaxşılaşdırılması zamanı qəbul edilə bilər. Alınmış nəticələrdə Türk şirkətlərinin müxtəlif ölkələrin tərəfdaş şirkətləri kimi informasiya texnologiyalarının təhlükəsizliyinə çox əhəmiyyət verilmədiyi göstərilmişdir.

[12]-də göstərilir ki, bir çox innovativ srtukturların, proseslərin informasiya təhlükəsizliyinin məsafədən idarə olunmasının arxitektur-texnoloji infrastrukturunun müasir kontekstdə işlənilməsinə ehtiyac formalaşmaqdadır. $\mathrm{Bu}$ prosesi həm proqram, həm də aparat-texniki vasitələrini innovativ effektiv strukturlaşdırılması yolu ilə həll etmək olar.

Texnoparkların fəaliyyətinin idarə edilməsində qərar qəbul etmə prosesi onun müasir informasiya təminatının formalaşmasını zəruri edir. Texnoparkların informasiya təminatı sistemi 1)müxtəlif idarəetmə orqanları ilə informasiya əlaqəsi, 2)inzibati idarə etmə sistemi bloku, 3)elm-təhsil strukturları ilə əlaqə, 4)i்T infrastruktur bloku, 5)İnternet, İnternet provayderləri, 6)beynəlxalq təşkilatlarla əlaqələndirmə bloku, 7)verilənlərin saxlanılması və emalı bloku (DATA mərkəz), 8)istehsal/xidmət, servis təminatı bloku, 9)daxili strukturlarla əlaqə bloku, 10)innovasiya xidmətlıri bloku, 11)regional strukturlarla informasiya əlaqələri bloku, 12)innovativ layihələrin idarə olunması bloku, 13)e-xidmətlər və elmi bazalara çıxış, 14)riyazi və proqram təminatı və s. kimi əsas struktur elemenlərindən, bloklardan təşkil olunmuşdur [4].

İdarə etmə prosesində informasiya təminatının əsas komponentləri 1)idarəetmə strukturlarını faktiki məlumatlarla təmin etmək, 2)avtomatlaşdırılmış idarəetmə sistemləri üçün informasiya təminatından istifadə, 3)müxtəlif təşkilatların idarəetmə fəaliyyətinin təminatı üçün informasiyadan istifadə, 4)informasiya mənbələrinin seçilməsi və təyini, 5)alınmış məlumatların düzgün interpretasiyası və sistemləşdirməsi, 6)verilənlərin etibarlılığının, tamlığının və ziddiyətsizliyinin yoxlanılması, 7)informasiyanın qəbulu, saxlanması və çoxaldılması məsələsi, 8)verilənlərin ötürülməsi üçün vahid formatda təqdimat, 9)alınmış informasiyanın təkrar istifadəsi, 10)məlumatların daimi yenilənməsi kimi məsələlər tədqiq olunmuşdur.

İnformasiya təminatı sistemi 1)informasiyanın toplanmas1, 2)informasiya dövriyyəsinin təşkili, 3)informasiyanın saxlanması, və aktuallaşdırılması, 4)informasiya sisteminin 


\section{“Informasiya tohlükosizliyinin aktual multidissiplinar elmi-praktiki problemlori” IV respublika konfransı, 14 dekabr 2018-ci il}

texniki təminat1, 5)informasiya sisteminin riyazi proqram təminat1, 6)informasiyanın verilməsi və s. kimi bir sıra elementləri özündə əks etdirir. Texnoparkın idarə etmə prosesində informasiya təminatının yaxşılaşmasına elmitexniki, təşkilatı-iqtisadi, sosial-psixoloji və hüquqi amillər təsir edir.

Elmi-texnoloji innovativ parkların informasiya təhlükəsizliyi sisteminin qurulması üçün ümumi prinsiplərə və yanaşmalara aşağıdakıları aid etmək olar [7]: 1)innovasiya fəaliyyəti subyektlərinin düzgün təhlükəsizlik strategiyasının müəyyənləşdirilməsi, innovativ strukturun fəaliyyət xüsusiyyətlərinin nəzərə alınması; 2)informasiyanın təhlükəsizliyi sahəsində çevik idarəetmə qərarlarının qəbulunun keyfiyyətinin yüksəldilməsi, 3)innovativ strukturlarda informasiya təhlükəsizliyi siyasətinin səmərəliliyinin yüksəldilməsi; 4)informasiyanın qorunması üzrə xüsusi xidmət qruplarının formalaşdırılması.

Elmi-texnoloji innovativ parkların informasiya təhlükəsizliyi xidmətinin əsas funksiyalarına aşağıdakıları daxil etmək olar: 1)strurkurda məxfi informasiyanın qorunmasının təşkili və həyata keçirilməsi; 2) strukturun fəaliyyəti haqqında məxfi məlumat əldə etmək məqsədi ilə işçi heyət ilə bağlı təxribatlar; digər hərəkətlər haqqında məlumatların yoxlanılması; 3)təhlükəsizlik məsələləri üzrə informasiyanın təhlili və avtomatlaşdırılmış uçotu, yı̆̆ım və toplanmasının təşkili; 4)sənaye sirri haqqında müddəaların hazırlanması və həyata keçirilməsi; 5)xüsusi idarəetmə qaydalarının yoxlanılması; 6)iqtisadi, informasiya və fiziki təhlükəsizlik qaydalarına riayət etmək üçün işçilərin yoxlanılması; 7)arzu olunmaz tərəfdaşlarla sazişlərin qarşısının alınması məqsədi ilə zəruri informasiyanın yığımı, emalı, saxlanması və analizi; 8)innovativ struktur rəhbərliyinin tapşırıqlarının yerinə yetirilməsi; 9)struktur işçilərinin rəsmi sənədlərinin təhlükəsizliyini təhdid edən məxfi informasiyanın açıqlanması ilə bağlı tədqiqatların aparılması.

Elmi-texnoloji innovativ parkların informasiya təhlükəsizliyinin əsas istiqamətləri aşağıdakılardır [7]: 1)informasiya təhlükəsizliyi sisteminin qurulması istiqamətində yerli problemlərin həlli; 2)təhlükəsizliyin təmin olunmasında təşkilatı-idarəetmənin rolunun artırılması; 3)informasiya təhlükəsizliyi sahəsində innovativ strukturun konsepsiyası və siyasətinin müəyyən edilməsi ilə başlayan informasiya təhlükəsizliyi sisteminin yaradılması; 4)informasiya təhlükəsizliyi sistemlərinin sınaq vəziyyətinin monitorinqi; 5)informasiya təhlükəsizliyi sistemlərinin fəaliyyətinin effektivliyinin qiymətləndirilməsində tətbiq edilən iqtisadi göstəricilərin müəyyənləşdirilməsi. Elmitexnoloji innovativ parkların informasiya təhlükəsizliyi siyasətinin işlənilməsi zamanı göstərilən tendensiya, prinsip və yanaşmalar nəzərə alınmalıdır.

\section{IV.ELMI-TEXNOLOJI INNOVASIYA TEXNOPARKLARININ INFORMASIYA TəHLÜKӘSIZLIYININ IDARӘ EDILMӘSI}

Texnoparklar üçün daha çox təhlükə yaradan hallar sırasına onun infrastrukturunu formalaşdıran yerli informasiya və telekommunikasiya sənayesinin fəaliyyətini və onun müvafiq məhsul istehsalı və xidmət göstərməsinin qarşısını alan situasiyaları aid etmək olar. Bundan başqa ictimai-zəruri informasiya resurslarına səmərəsiz və həddən artıq olan məhdudiyyətlər, açıq informasiya fondlarına girişin məhdudlaşdırılması və $\mathrm{s}$. kimi innovativ texnologiyalarıntətbiqinin aşağı salınmasına yönəlmiş tədbirləri do bu siraya aiddir. Eyni zamanda informasiya manipulyasiyası, yeni informasiya texnologiyalarından istifadəyə qarşı hərəkətlər, intellektual mülkiyyət sahiblərinin xaricə axını, informasiya emalı texnologiyaları prosedurunun pozulması, şəbəkələrdə informasiyanın ələ keçirilməsi və onlardan dezinformasiya və digər bəd niyyətlərlə istifadə olunması da təhlükə mənbəyi hesab olunur [6].

Texnoparkların təhlükəsizlik siyasətinin reallaşdırması üçün informasiyanın mühafizəsi metodlarına aşağıdakılar daxildir [8]: 1)müdafiə edilən obyektlərdə kompleks müdafiənin reallaşdırılmasına imkan verən texniki vasitələr və təşkilati tədbirlər; 2)müdafiənin əsas vasitələrinin seçimi və yerləşdirilməsi üçün təklif və tövsiyələr; 3)informasiya təhlükəsizliyi sisteminin tətbiqinin texniki-iqtisadi əsaslandırılması; 4)mümkün təhlükələrin qiymətləndirilməsi, itkilərin ölçülərini nəzərə almaqla sistemin effektivliyinin qiymətləndirilməsi; 5)informasiya təhlükəsizliyi siyasətinin dəstəklənməsi və reallaşdırılması üzrə planın hazırlaması; 6)müəssisədə informasiya təhlükəsizliyi sistemlərinin inkişafı və təkmilləşdirilməsi ilə bağlı təkliflərin hazırlanması; 7)təklif olunan mühafizə tədbirlərinin səmərəliliyini nəzərə alaraq innovasiya struktiurunun səmərəliliyin qiymətləndirilməsi.

Elmi-texnoloji innovasiya texnoparklarının informasiya təhlükəsizliyinin arxitektur sxemini şəkil 1-dəki kimi vermək olar [13].

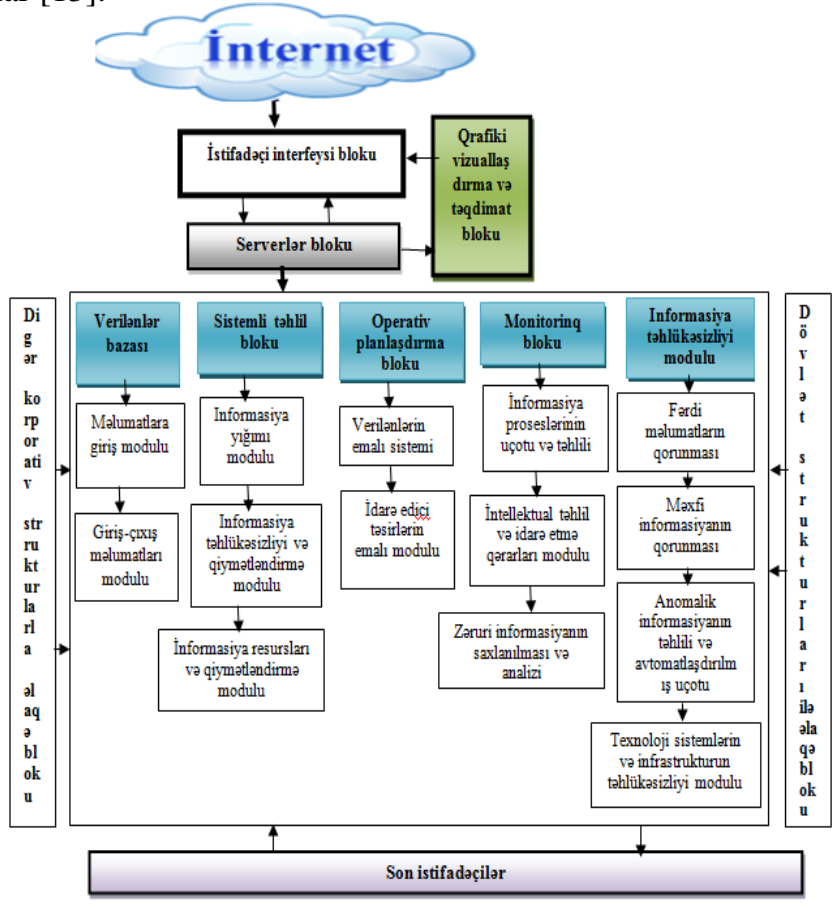

Şəkil 1. Elmi-texnoloji innovasiya texnoparklarının informasiya təhlükəsizliyi sisteminin arxitektur-texnoloji strukturu 


\section{“Informasiya tohlükosizliyinin aktual multidissiplinar elmi-praktiki problemlori” \\ IV respublika konfransı, 14 dekabr 2018-ci il}

Texnoparkların ümumi təhlükəsizlik konsepsiyasına müvafiq olaraq informasiya mühafizəsi xidmətinin praktiki fəaliyyəti nümunəvi sxem, prosedur və fəaliyyətə əsaslanır. Burada ilk növbədə həmin fəaliyyətin müəyyən ardıcıl mərhələlər üzrə həyata keçirildiyini qeyd etmək lazımdır (şəkil 2). Texnoparkların fəaliyyətində mövcud təhlükələrin struktur təhlili informasiya risklərini müəyyənləşdirməyə və nəticə etibarı ilə həmin strukturun dayanıqlı kompleks fəaliyyət proqramını işləməyə imkan verir. Risklərin idarə olunması üçün daxili və xarici təhlükə mənbələrini müəyyən etmək və həmin təhlükə ilə yaranacaq risk və fəaliyyət nəticələri arasındakı səbəb-nəticə əlaqələrini aşkarlamaq zəruridir.

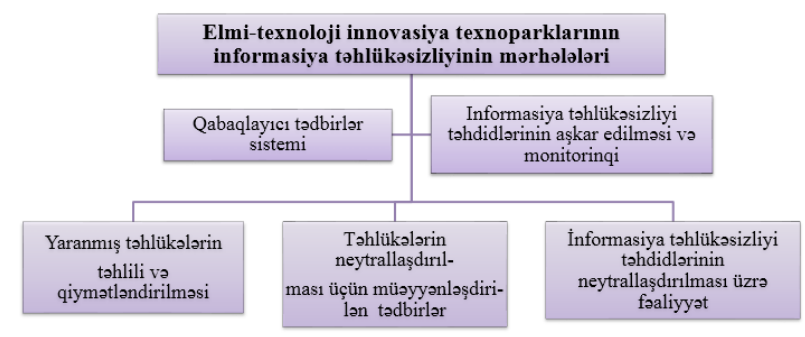

Şəkil 2. Elmi-texnoloji innovasiya texnoparklarının informasiya təhlükəsizliyinin idarə olunması mərhələləri

Texnoparkların fəaliyyətində informasiya təhlükəsizliyinin təkmilləşdirilməsi üçün bir sira məsələlərə baxılır və həll edilir: 1)texnoparkın informasiya təhlükəsizliyinin təminatı üçün məqsədli proqramın işlənilməsi, 2)texnoparkın informasiya təhlükəsizliyinin təminatı sisteminin inkişaf etdirilməsi və təkmilləşdirilməsi, 3)vahid dövlət siyasətini həyata keçirməklə informasiya təhlükəsinin proqnozlaşdırılması və qiymətləndirilməsi üzrə üsul və formaların təkmilləşdirilməsi, 4)strukturun informasiya təhlükəsizliyinin təminatı vasitələri və sistemlərinin səmərəliliyinin qiymətləndirilməsi üzrə metod və kriteriyalarının işlənilməsi, 5)informasiya təhlükəsizliyinin təminatı sahəsində bütün innovativ müəssisə və təşkilatların fəaliyyətinin əlaqələndirilməsi, 6)milli iqtisadiyyatın vacib sahələrində texnoparkların texnoloji müstəqilliyinin təmin olunması, 7)texnoparklarda informasiyanın mühfizə edilməsində müasir üsul, metodların işlənilməsi və yeni texnologyların tətbiqi, 8)informasiya təhlükəsizliyinin təmin olunmasında elmi-texniki və hüquqi məsələlərin həllində beynəlxalq orqanlarla və təşkilatlarla qarşılıqlı əlaqələrin genişlənləndirilməsi, 9)qlobal informasiya şəbəkələri və sistemlərinin yaradılması proseslərində regional iştirakın təmini, 10)texnoparklar üçün informasiya təhlükəsizliyi və informasiya texnologiyaları sahəsində kadrların hazırlanması üzrə vahid sistemin yaradılması.

\section{ELMI-TEXNOLOJI INNOVATIV PARKLARDA INFORMASIYA TӘHLÜKӘSIZLIYI METODLARI}

İnformasiya təhlükəsizliyinin 1)tamlıq, 2)gizlilik, 3)əlyetənlilik və s. kimi komponentləri vardır [14].
Elmi-texnoloji innovativ parkların fəaliyyətində informasiya təhlükəsizliyinin təmin edilmə metodları təhlükələrin idarə olunmasına vahid yanaşmanı nəzərdə tutur. Buna baxmayaraq belə strukturların spesifik fəaliyyət sahəsi olması faktı nəzərə alınmalıdır [9-13]. Texnoparkların ümumi təhlükəsizlik metodları ilə yanaşı təhlükələrin spesifikasından asılı olaraq xüsusi metodlar və prosedurlar da tətbiq olunur.

Elmi-texnoloji innovasiya texnoparklarında informasiya təhlükəsizliyinin ümumi metodlarına aşağıdakıları aid etmək olar: 1)informasiya təhlükəsizliyi sahəsində münasibətləri tənzimləyən qanunvericiliyin təkmilləşdirilməsi; 2)istifadəçilərin icazəsiz girişinə görə məsuliyyətin müəyyənləşdirilməsi; 3)milli şəbəkələrin inkişafı prioritetinin qanunvericilik səviyyəsinin gücləndirilməsi; 4)informasiya təhlükəsizliyin təminatı sisteminin yaradılması, təkmilləşdirilməsi və idarə edilməsi; 5)informasiyanın qorunma vasitələrinin effektivliyinə nəzarət metodlarının təkmilləşdirilməsi, istifadəsi və işlənilməsi; 6)informasiya təhlükəsizliyinin təminatı sahəsində kadrların hazırlanması; 7)informasiya təhlükəsizliyinin göstəriciləri üzrə monitorinq sisteminin formalaşması; 8)informasiya təhlükəsizliyinin təminatı və onun maliyyələşdirilməsinin nizamlanması; 9)təhlükəsizlik sistemlərinin iqtisadi əsaslandırılması; 10)təhlükəsizliklə bağlı ziyanların qiymətləndirilməsi və s.

\section{NəTİ๐}

İnformasiya və biliklərə əsaslanan iqtisadiyyatın qurulmasında elmi-texnoloji innovasiya texnoparklarının yaradılması hazırkı dövr üçün zəruridir. Rəqəmsal və ya innovativ iqtisadiyyata keçid üçün yüksək texnologiyalar parkı, elm-texnoloji innovasiya texnoparkları əsas hərəkətverici qüvvədir. Texnoparkların informasiya sistemləri və texnologiyalarının təhlükəsizliyi problemlərinin ümumi təhlili və idarə olunması üzrə fəaliyyət planının işlənilməsi zərurudir. İnnovativ fəaliyyətin yüksək rəqabətqabiliyyətliliyi üçün həmin strukturun sosial kommersiya maraqlarına ziyan vura biləcək daxili və xarici təhlükələrdən qorunması üzrə düzgün təhlükəsizlik sistemi işlənilməli və tətbiq olunmalıdır. Hər bir innovativ texnopark strukturunun qarşısında duran təhlükəsizlik məsələsinin həlli, həm də ümumi təhlükəsizlik siyasəti çərçivəsində tənzimlənməli və koordinasiya olunmalıdır. Bununla yanaşı innovativ texnoparkların təhlükəsizlik sisteminin monitorinqi həyata keçirilməli və müntəzəm olaraq aşkarlanmış təhlükələr sistemləşdirilməli, qiymətləndirilməli və onların aradan qaldırılması üçün müvafiq tədbirlər həyata keçirilməlidir.

\section{ӘDӘВIYYAT}

[1]. Milli iqtisadiyyat və iqtisadiyyatın əsas sektorları üzrə Strateji Yol Xəritələri. Bakı, 6 dekabr 2016-cı il, www.president.az.

[2]. Azərbaycan Respublikasında Informasiya Cəmiyyətinin Inkişafına dair 2014-2020-ci illər üçün Milli Strategiya. 02.04.2014-cü il, www.president.az.

[3]. O.Q.Oliyev, R.O.Şahverdiyeva. İnnovativ struktur və proseslərin idarə olunmasında informasiya təhlükəsizliyi məsələləri. İnformasiya təhlükəsizliyinin multidistiplinar problemləri üzrə II respublika elmipraktiki konfransı, 14 may 2015-ci il, səh. 66-69. 
[4]. R.M.Alguliyev, A.G.Aliyev, R.O.Shahverdiyeva. Development of information support systems for management of innovative structures. The 8th IEEE International Conference on Application of Information and Communication Technologies (AICT2014). Kazakhstan, Astana, 15-17 october 2014, pp. 378-382.

[5]. Э.Q.Oliyev, R.O.Şahverdiyeva. İnformasiya iqtisadiyyatında innovasiyalar üzrə monitorinq sisteminin göstəricilər bazasının işlənilməsinin konseptual əsasları. İnformasiya Cəmiyyəti Problemləri, 2014, №2, səh.50-60.

[6]. Е.Г.Горшков. Информационная безопасность управления интеллектуально-промышленными комплексами - технопарками в Российской Федерации. Вестник ОУ. Серия «Экономика», 2007, № 2, с. 127-131.

[7]. Massimo Felici. Economics, Security and Innovation. Economics of grids, clouds, systems, and services. Lecture notes in computer science, volume 8914, 2014, pp.3-15.

[8]. Menggang Li. Research on industrial security theory. Basic theories of industrial security, 2013, pp.69-169.

[9]. Н.В.Бозо. А.В.Динер. Методический подход к оценке эффективности деятельности технопарков. Вестник ТГУ, Экономика, 2016, №1(33), с. 105-115.

[10]. Laleh Esmaeil, Masoudi Yosefç Fathy Farhad, et al. Influencing Factors of Information Security Management in Small- and Mediumsized Enterprises and Organizations. 3rd International Conference on Communication Systems and Network Technologies (CSNT). India, apr. 06-08, 2013. Book Series: International Conference on Communication Systems and Network Technologies, pp. 445-449.

[11]. Yildirim Ebru Yeniman, Akalp Gizem Aytac, Serpil et al. Factors influencing information security management in small-and mediumsized enterprises: A case study from Turkey. International journal of information management, 2011, volume 31, issue 4, pp.360-365.

[12]. Jian Zhao, Yang Chen. An innovative structure of information security equipment for remote control. 5th International conference on Information Engineering for Mechanics and Materials (ICIMM). China, Jul. 25-26, 2015. Book Series: AER-Advances in Engineering Research, volume 21, pp.1002-1006.

[13]. С.С.Козунова. Система управления информационной безопасностью предприятия. Евразийский Союз Ученых (ЕСУ), Технические Науки, 2016, №7(28), pp.22-23.

[14]. В.И.Кияев, А.В.Саитов. Комплексная информационная безопасность в управлении современным предприятием : учебное пособие, -СПб. : Изд-во СПбГЭУ, 2016, 222 с.

\section{INFORMATION SECURITY PROBLEMS OF SCIENTIFIC-TECHNOLOGICAL INNOVATION TECHNOPARKS}

Shahverdiyeva O. Roza

Institute of Information Technology of ANAS, Baku, Azerbaijan shahverdiyevar@gmail.com

Abstract - The article is devoted to problems of information systems and technologies of scientific and technological innovation technoparks. The role, tasks and importance of innovation technoparks in the economy of information and knowledge are explained. In their management, the key elements of the modern information supply system and the factors influencing the improvement of information have been interpreted. Stages of formation of information systems, resources and technologies of technoparks are presented. The architectural-technological structure of the information security system has been developed and some recommendations have been provided for its improvement.
Key words. information and knowledge economy; scientific and technological innovation technopark; security of information systems; information provision and security; security methods. 